\title{
PEMANFAATAN E-COMMERCE DALAM MENINGKATKAN PENDAPATAN KELUARGA
}

\author{
Asye Rachmawaty, S.T., M.M. \\ Dosen Program Studi Manajemen Informatika \\ Politeknik LP3I Bandung \\ e-mail: asyerachmawaty@gmail.com
}

\begin{abstract}
Abstrak: Penelitian ini membahas tentang pemanfaatan e-commerce sebagai sarana dalam melakukan transaksi jual-beli yang dilakukan oleh para pelaku bisnis online, dalam hal ini ibu rumah tangga yang berusaha meningkatkan pendapatan keluarga.

Metode penelitian yang digunakan adalah deskriptif. Unit analisis dalam penelitian adalah ibu rumah tangga sebagai pelaku bisnis online dengan jumlah populasi sebanyak 25 orang. Tipe investigasi kausalitas dengan time horizon ini adalah cross-sectional.

Berdasarkan hasil penelitian dan pembahasan, diperoleh bahwa dengan memanfaatkan e-commerce dalam melakukan bisnis, ibu rumah tangga dapat meningkatkan pendapatan keluarganya.
\end{abstract}

Kata Kunci: Pemanfaatan e-commerce, Media Sosial, Peningkatan Pendapatan.

\section{Pendahuluan}

Teknologi informasi merupakan bentuk teknologi yang digunakan untuk menciptakan, menyimpan, mengubah, dan mengunakan imformasi dalam segala bentuknya. Melalui pemanfatan teknologi informasi ini, perusahaan dapat memasuki pasar global. Pemanfatan teknologi informasi dalam menjalankan bisnis atau sering dikenal dengan istilah e-commerce bagi perusahan dapat memberikan

fleksibiltas dalam produksi, mengirimkan dan menerima pesanan secara cepat dan hemat, serta mendukung transaksi cepat tanpa kertas. Pemanfatan internet memungkinkan pelaku usaha melakukan pemasaran dengan tujuan pasar global, sehinga peluang menembus ekspor sangat mungkin. (Prastuti Sulistyorini dkk., 2014:104)

E-commerce merupakan konsep baru yang bisa digambarkan sebagai proses jual beli barang atau jasa pada Internet atau proses jual beli atau pertukaran produk, jasa dan informasi melalui jaringan informasi termasuk di internet. E-commerce dapat dilihat dari beberapa perspektif yaitu: (1) Perspektif Komunikasi: ecommerce merupakan pengiriman informasi, produk/ layanan, atau pembayaran melalui lini telepon, jaringan komputer atau sarana eletronik lainnya. (2) Perspektif Proses Bisnis: e-commerce merupakan aplikasi teknologi menuju 
otomisasi transaksi dan aliran kerja perusahaan. (3) Perspektif Layanan: $e$ commerce merupakan salah satu alat yang memenuhi keinginan perusahaan, konsumen dan manajemen dalam memangkas service cost ketika meningkatkan mutu barang dan kecepatan pelayanan. (4) Perspektif Online: e-commerce berkaitan dengan kapasitas jual beli produk dan informasi di internet dan jasa online lainnya. (Suyanto, 2003)

Penelitian sebelumnya yang dilakukan oleh Siti Maryama (2013) dengan judul Penerapan E-commerce dalam Meningkatkan Daya Saing Usaha, menyimpulkan bahwa motif pelaku usaha menerapkan e-commerce adalah untuk mengakses pasar global, mempromosikan produk; membangun merk, mendekatkan dengan pelanggan, membantu komunikasi lebih cepat dengan pelanggan, dan dalam rangka memuaskan pelanggan. Sedangkan manfaat yang dirasakan oleh pelaku ketika menerapkan e-commerce adalah meningkatkan omzet penjualan, meningkatkan jumlah pelanggan, sebagai sarana promosi, dan dapat memperluas bisnis.

Prastuti Sulistyorini dkk. (2014), melalui penelitiannya yang berjudul Pengaruh Adopsi E-Commerce Terhadap Keberhasilan Usaha, menyatakan bahwa faktor manfaat mempunyai pengaruh signifikan dan positif terhadap pengadopsian $e$ commerce. Sehingga dapat disimpulkan bahwa semakin tinggi manfaat maka pengadopsian e-commerce akan berjalan semakin baik.

Berdasarkan beberapa penelitian sebelumnya, dapat ditarik kesimpulan bahwa para pelaku usaha saat ini dalam menunjang keberhasilan usahanya, dengan memanfaatkan e-commerce.

Bisnis online dengan e-commerce bukan hanya menjadi sasaran para pelaku industri menengah ataupun besar, tapi juga sudah menjadi alat untuk menjalankan bisnis industri kecil atau rumah tangga. Para pelaku bisnis online skala kecil atau rumah tangga tidak harus membuat website dalam menjalankan bisnisnya, cukup dengan membuat beberapa akun Facebook; Instagram; Twitter; dan atau Blog, kemudian meng-upload foto-foto produk yang dipasarkan, dan memberikan keterangan kepada pengunjung untuk memesan ataupun meminta info lebih lanjut melalui Blackberry Messenger, WhatsApp, LINE, dan telepon.

Saat ini banyak ibu rumah tangga dengan segala aktifitas menjalankan kewajibannya, juga mampu menjalankan bisnis sampingan dengan berjualan secara online. Facebook adalah salah satu jejaring sosial yang menjadi pilihan utama bagi para pelaku bisnis online, terutama para ibu rumah tangga. Mereka memanfaatkan waktu luang disela-sela aktifitasnya untuk melakukan promosi dengan cara mengunggah berbagai gambar melalui akun atau FanPage Facebook, memberikan penjelasan mengenai detail gambar, dan mencantumkan keterangan alamat atau nomor seperti PIN Blackberry Messenger; WhatsApp; LINE; dan nomor telepon dimana para pelanggan dapat menghubunginya untuk melakukan transaksi. Pelanggan dapat bertanya mengenai produk yang dipasarkan dengan cara memberikan komentar ataupun melalui pesan pribadi. Beberapa diantara mereka adalah sebagai distributor yang melayani partai besar/grosir dan eceran, beberapa melakukan MLM (Multi Level Marketing) yang tidak hanya melakukan 
penjualan produk tetapi juga mengajak menjadi rekan bisnis, dan sebagian lagi menjadi reseller atau dropship yang melakukan penjualan kembali produk-produk yang dipasarkan oleh pelaku bisnis lainnya. Produk yang dipasarkan bermacammacam seperti: pakaian; makanan; kosmetik; alat rumah tangga; produk perawatan; alat kesehatan; mainan; dan juga perlengkapan bayi dan anak.

Berdasarkan observasi, rata-rata usia ibu rumah tangga pelaku bisnis termasuk dalam usia produktif (22-40 tahun), usia perkawinan dalam rentang 2-13 tahun, dengan jumlah anak rata-rata dua orang dan berumur dibawah 12 tahun.

Maraknya penjualan secara online yang dilakukan oleh para ibu rumah tangga dalam uasaha meningkatkan pendapatan keluarga membuat peneliti ingin mengetahui tingkat keberhasilan pemanfaatan e-commerce pada bisnis online yang dilakukan ibu rumah tangga dalam usaha meningkatkan pendapatan keluarga.

\section{Tinjauan Pustaka}

\section{a. E-commerce dan manfaatnya}

E-commerce dapat diartikan sebagai suatu proses berbisnis dengan menggunakan teknologi elektronik yang menghubungkan antara perusahaan, konsumen dan masyarakat dalam bentuk transaksi elektronik dan pertukaran/penjualan barang, servis, dan informasi secara elektronik (Munawar, 2009:1). Jony Wong (2010:33) mengemukakan bahwa $e$ commerce adalah pembelian, penjualan dan pemasaran barang serta jasa melalui sistem elektronik. Seperti televisi, radio dan jaringan komputer atau internet.

Manfaat e-commerce menurut Suyanto (2003, 50:51):

1) Bagi Organisasi pemilik e-commerce

a) Memperluas market place hingga kepasar nasional dan internasional.

b) Dengan capital outplay yang minim, sebuah perusahaaan dapat dengan mudah menemukan lebih banyak pelanggan, supplier yang lebih baik dan partner bisnis yang paling cocok dari seluruh dunia.

c) E-commerce menurunkan biaya pembuatan, pemrosesan, pendistribusian, penyimpanan, dan pencarian informasi yang menggunakan kertas.

d) E-commerce mengurangi waktu antara outplay modal dan penerimaan produk dan jasa.

2) Bagi konsumen

a) E-commerce memungkinkan pelanggan untuk berbelanja atau melakukan transaksi selama 24 jam sehari sepanjang tahun dari hampir setiap lokasi.

b) E-commerce memberikan lebih banyak pilihan kepada pelanggan, mereka bisa memilih berbagai produk dari banyak vendor. 
c) E-commerce menyediakan produk dan jasa yang tidak mahal kepada pelanggan dengan cara mengunjungi banyak tempat dan melakukan perbandingan secara cepat.

d) Pelanggan bisa menerima informasi yang relevan secara detil dalam hitungan detik, bukan lagi hari atau minggu.

3) Bagi masyarakat

a) E-commerce memungkinkan orang untuk bekerja didalam rumah dan tidak harus keluar rumah untuk berbelanja. Ini berakibat menurunkan arus kepadatan lalu lintas dijalan serta mengurangi polusi udara.

b) E-commerce memungkinkan orang di negara-negara dunia ketiga dan wilayah pedesaan untuk menikmati aneka produk dan jasa yang akan susah mereka dapatkan tanpa e-commerce.

Rachmat Hidayat (2014) dalam jurnal teknologi yang berjudul FaktorFaktor Yang Mempengaruhi Pengaplikasian E-commerce menyatakan bahwa terdapat enam faktor baru yang mempengaruhi seseorang melakukan implementasi bisnis menggunakan media e-commerce. Keenam faktor tersebut adalah:

1) Optimalisasi

Berusaha untuk mengoptimalkan segala sesuatu yang melibatkan responden, misalnya pengiriman barang; balas pesan, dan lain-lain agar responden merasa puas dengan pelayanan kita.

2) Keberagaman barang

Barang yang bisa dipasarkan melalui media e-commerce sangat beragam, jadi apapun yang sekiranya layak jual, bisa untuk dipasarkan.

3) Area pemasaran

Wilayah pemasaran melalui media e-commerce tidak ada batasan selama tempat tersebut terdapat internet, e-commerce bisa masuk.

4) Perluasan bisnis

Melakukan pengembangan serta perluasan sektor bisnis melalui pembaruan barang yang diperjual-belikan serta cara yang dipakai agar dapat memudahkan konsumen dalam melakukan transaksi.

5) Keberagaman konsumen

Konsumen yang terlibat dalam perdagangan melalui media $e$ commerce berasal dari semua segmen, mulai dari para remaja sampai usia lanjut.

6) Promosi

Promosi melalui media online merupakan usaha yang sifatnya virtual, tidak akan ada yang mengetahui jika tidak di share pada khalayak umum.

Adapun tahapan proses transaksi e-commerce adalah sebagai berikut:

1) Show

Penjual menunjukkan produk atau layanannya di situs yang dimiliki, lengkap dengan detail spesifikasi produk dan harganya. 
2) Register

Konsumen melakukan register untuk memasukkan data-data identitas, alamat pengiriman dan informasi login.

3) Order

Setelah konsumen memilih produk yang diinginkan, konsumen pun selanjutnya melakukan order pembelian.

4) Payment

Konsumen melakukan pembayaran.

5) Verification

Verifikasi data konsumen sepeti data-data pembayaran (nomor rekening atau kartu kredit).

6) Deliver

Produk yang dipesan pembeli kemudian dikirimkan oleh penjual ke konsumen.

\section{b. Media Sosial}

Social media atau dalam bahasa indonesia disebut media sosial adalah media yang didesain untuk memudahkan interaksi sosial yang bersifat interaktif atau dua arah. Media sosial berbasis pada teknologi internet yang mengubah pola penyebaran informasi dari yang sebelumnya bersifat satu ke banyak audiens, banyak audiens ke banyak audiens (Paramitha, 2011:42).

Menurut Gunelius (2011: 10) media sosial adalah penerbitan online dan alat-alat komunikasi, situs, dan tujuan dari Web 2.0 yang berakar pada percakapan, keterlibatan, dan partisipasi.

Aditya Firmansyah (2010:10) mengemukakan bahwa situs jejaring/media sosial merupakan sebuah situs berbasis pelayanan yang memungkinkan penggunanya untuk membuat profil, melihat list pengguna yang tersedia, serta mengundang atau menerima teman untuk bergabung dalam situs tersebut. Tampilan dasar situs jejaring sosial ini menampilkan halaman profil pengguna, yang di dalamnya terdiri dari identitas diri dan foto pengguna.

Berdasarkan teori-teori tersebut di atas, dapat disimpulkan bahwa media sosial adalah media online yang dibuat dengan tujuan kemudahan interaksi sosial yang bersifat interaktif, sebagai alat komunikasi dimana penggunanya dapat membuat profil, melihat profil pengguna lain, mengundang atau menerima pertemanan dalam situs tersebut.

\section{c. Social Media Marketing}

Pemasaran media sosial atau sering disebut social media marketing adalah bentuk pemasaran langsung atau tidak langsung yang digunakan untuk membangun kesadaran, pengakuan, ingat, dan tindakan untuk merek, bisnis, produk, orang, atau badan lain dan dilakukan dengan menggunakan alat-alat dari Web sosial, seperti sebagai berbagi blogging, mikrobloging, jejaring sosial, bookmark sosial, dan konten. Social media marketing mencakup taktik tertentu seperti berbagi kupon atau mengumumkan penjualan di facebook atau twitter, atau bisa mencakup lebih luas membangun merek inisiatif seperti berkomunikasi dengan orang-orang 
atau menciptakan konten yang menarik di blog, dalam sebuah video yang diunggah ke YouTube atau dalam presentasi bersama berbagi slide. Selain itu, pemasaran media sosial menawarkan kesempatan besar untuk pengusaha, usaha kecil, perusahaan menengah, dan perusahaan besar untuk membangun merek mereka dan bisnis mereka (Gunelius, 2011:10).

Genelius (2011:15) juga mengemukakan tujuan pemasaran media sosial yang paling utama adalah sebagai berikut:

1) Membangun hubungan: manfaat utama dari pemasaran media sosial adalah kemampuan untuk membangun hubungan dengan konsumen secara aktif.

2) Membangun merek: percakapan melalui media sosial menyajikan cara sempurna untuk meningkatkan brand awareness, meningkatkan pengenalan dan ingatan akan merek dan meningkatkan loyalitas merek.

3) Publisitas: pemasaran melalui media sosial menyediakan outlet di mana perusahaan dapat berbagi informasi penting dan memodifikasi persepsi negatif.

4) Promosi: melalui pemasaran media sosial, memberikan diskon eksklusif dan peluang untuk audiens untuk membuat orang-orang merasa dihargai dan khusus, serta untuk memenuhi tujuan jangka pendek.

5) Riset pasar: menggunakan alat-alat dari web sosial untuk belajar tentang pelanggan, membuat profil demografi dan perilaku pelanggan, belajar tentang keinginan dan kebutuhan konsumen, serta belajar tentang pesaing.

\section{Metode Penelitian}

\section{a. Jenis Penelitian}

Jenis penelitian ini termasuk penelitian survei, dan dalam pengambilan kesimpulan dilakukan dengan melalui studi komparasi. Objek penelitian adalah ibu rumah tangga sebagai pelaku bisnis online. Kuesioner untuk mengetahui tingkat keberhasilan pemanfaatan e-commerce terhadap peningkatan pendapatan keluarga dibagikan kepada 25 ibu rumah tangga pelaku bisnis online sebagai sampel. Penetapan sampel dilakukan dengan teknik purposive sampling method, dimana pengambilan sampel ditentukan secara sengaja/sesuai dengan masalah penelitian.

\section{b. Metode Pengumpulan Data}

Metode pengumpulan data dilakukan dengan:

1) Kuesioner

Pencarian data dilakukan dengan membagi kuesioner kepada para ibu rumah tangga pelaku bisnis online yang berdomisili di Bandung.

2) Wawancara

Wawancara dilakukan untuk mendapatkan gambaran yang lebih detail mengenai obyek penelitian. 


\section{c. Variabel Penelitian dan Operasional Variabel}

Variabel yang terdapat dalam penelitian ini adalah variabel terikat (dependen) dan variabel bebas (Independen). Variabel bebas adalah variabel yang mempengaruhi variabel lain, sedangkan variabel terikat adalah variabel yang dipengaruhi oleh variabel lain. Variabel terikat pada penelitian ini adalah Pemanfaatan e-commerce dan variabel bebas pada penelitian ini yaitu Peningkatan Pendapatan Keluarga.

Data primer, yaitu data yang diperoleh langsung dari responden dikumpulkan dengan menggunakan kuesioner dan skala likert (ordinal) dengan metode rating yang dijumlahkan.

Menghitung rata-rata (mean) dari masing-masing variabel penelitian. Kriteria yang digunakan untuk penafsiran hasil olah data adalah:

Tabel. 1 Kriteria Penafsiran Kondisi Variabel X dan Y

\begin{tabular}{|l|l|l|}
\hline No & Rata-rata Skor & Penafsiran \\
\hline 1 & $4,21-5,00$ & Sangat Setuju \\
\hline 2 & $3,41-4,20$ & Setuju \\
\hline 3 & $2,61-3,40$ & Ragu-ragu \\
\hline 4 & $1,81-2,60$ & Tidak Setuju \\
\hline 5 & $1,00-1,80$ & Sangat Tidak Setuju \\
\hline
\end{tabular}

\begin{tabular}{|c|c|}
\hline $\begin{array}{c}\text { Pemanfaatan } \\
\text { e-commerce } \\
(\mathrm{X})\end{array}$ & $\begin{array}{c}\text { Peningkatan } \\
\text { Pendapatan } \\
(\mathrm{Y})\end{array}$ \\
\hline
\end{tabular}

\section{d. Hubungan Antar Variabel}

Gambar 1: Hubungan antar Variabel

\section{Hasil dan Pembahasan \\ a. Karakteristik Responden}

Penelitian ini menggunakan metode survey, yang menguraikan sebagian pelaku bisnis online terlebih dahulu sebelum melakukan analisis verifikatif untuk mengetahui perilaku dari data itu sendiri, seperti sebagian besar responden mengenai status bisnis, usia, jenis produk, tingkat pendapatan, 
dan lain-lain. Berdasarkan hasil pengumpulan data melalui penyebaran kuesioner kepada 25 ibu rumah tangga pelaku bisnis online yang dijadikan sebagai responden, maka dapat diketahui sebagian besar responden mengharapkan agar informasi ini dapat dijadikan sebagai masukan bagi para pelaku bisnis online dalam menyusun strategi pemasaran dan penjualan yang sesuai bagi para pelaku bisnis online di masa yang akan datang untuk mencapai tujuan yang lebih baik. Karakteristik responden yang dapat disajikan dalam penelitian ini meliputi: status bisnis, usia, jenis produk, tingkat pendapatan.

Tabel 2: Karakteristik berdasarkan Status Bisnis

\begin{tabular}{|l|c|c|}
\hline \multicolumn{1}{|c|}{ Status Bisnis } & Frekuensi (Orang) & Presentase (\%) \\
\hline Utama & 10 & 40 \\
\hline Sampingan & 15 & 60 \\
\hline Jumlah & 25 & 100 \\
\hline
\end{tabular}

Sumber: Hasil pengolahan data

Tabel 2 di atas menyatakan bahwa sebagian besar ibu rumah tangga pelaku bisnis yang dijadikan responden menurut status bisnis adalah sampingan, dimana responden menjadikan bisnis online sebagai usaha sampingan untuk menunjang pendapatan utamanya.

Tabel 3: Karakteristik berdasarkan Usia

\begin{tabular}{|l|c|c|}
\hline \multicolumn{1}{|c|}{ Usia } & Frekuensi (Orang) & Presentase (\%) \\
\hline 20-25 tahun & 4 & 16 \\
\hline $26-30$ tahun & 5 & 20 \\
\hline $31-35$ tahun & 10 & 40 \\
\hline $36-40$ tahun & 5 & 20 \\
\hline$>41$ tahun & 1 & 4 \\
\hline Jumlah & 25 & 100 \\
\hline
\end{tabular}

Sumber: Hasil pengolahan data

Tabel 3 di atas menyatakan bahwa sebagian besar ibu rumah tangga pelaku bisnis yang dijadikan responden menurut usia adalah penduduk usia produktif. Penduduk usia produktif adalah penduduk yang berusia 15 hingga 59 tahun. penduduk muda berusia dibawah 15 tahun umumnya dianggap sebagai sebagai penduduk yang belum produktif karena secara ekonomis masih tergantung pada orang tua atau orang lain yang menanggungnya. Selain itu, penduduk berusia diatas 59 tahun dianggap tidak produktif lag karena kemampuannya tidak bisa optimal dalam 
melakukan pekerjaan. (Badan Kependudukan dan Keluarga Berencana Nasional, 2013).

Tabel 4: Karakteristik berdasarkan Jenis Produk

\begin{tabular}{|l|c|c|}
\hline \multicolumn{1}{|c|}{ Jenis Produk } & Frekuensi (Orang) & Presentase (\%) \\
\hline Pakaian dewasa & 5 & 20 \\
\hline Perlengkapan bayi dan anak & 9 & 36 \\
\hline Aneka makanan & 6 & 24 \\
\hline Kosmetik dan perawatan tubuh & 5 & 20 \\
\hline Jumlah & 25 & 100 \\
\hline
\end{tabular}

Sumber: Hasil pengolahan data

Tabel 4 di atas menyatakan bahwa sebagian besar ibu rumah tangga pelaku bisnis yang dijadikan responden lebih banyak menjual produk perlengkapan bayi dan anak.

Tabel 5: Karakteristik berdasarkan Tingkat Pendapatan

\begin{tabular}{|c|c|c|}
\hline $\begin{array}{c}\text { Pendapatan per Bulan } \\
\text { (Rp.) }\end{array}$ & Frekuensi (Orang) & Presentase (\%) \\
\hline$<500.000$ & 2 & 8 \\
\hline $500.000-1.500 .000$ & 10 & 40 \\
\hline $1.500 .000-2.500 .000$ & 4 & 16 \\
\hline $2.500 .000-3.500 .000$ & 5 & 20 \\
\hline$>3.500 .000$ & 4 & 16 \\
\hline Jumlah & 25 & 100 \\
\hline
\end{tabular}

Sumber: Hasil pengolahan data

Tabel 5 di atas menyatakan bahwa sebagian besar ibu rumah tangga pelaku bisnis yang dijadikan responden menurut tingkat pendapatan rata-rata adalah berkisar antara Rp. 500.000 s.d. Rp. 3.500.000.

\section{b. Pemanfaatan e-commerce bagi Ibu Rumah Tangga Pelaku Bisnis Online}

Analisis deskriptif data implementasi kuesioner variabel pemanfaatan $e$ commerce $(\mathrm{X})$ sebanyak 16 pertanyaan. Berikut merupakan hasil analisis deskriptif data kuesioner untuk variabel pemanfaatan e-commerce (X) yang dilakukan kepada 25 responden:

Tabel 6: Deskriptif Statistik Data Kuesioner Variabel Pemanfaatan E-commerce

\begin{tabular}{|l|l|l|l|}
\hline No. & Indikator Pertanyaan & Skor & Keterangan \\
\hline 1 & Mengoptimalkan pengiriman barang & 113 & Sangat setuju \\
\hline 2 & Ready stock pelayanan tanpa batas & 100 & Setuju \\
\hline 3 & Memberikan & Setuju \\
\hline
\end{tabular}




\begin{tabular}{|l|l|l|l|}
\hline & waktu & & \\
\hline 4 & Penjualan barang yang lebih variatif & 97 & Setuju \\
\hline 5 & Kemudahan operasional & 108 & Sangat setuju \\
\hline 6 & Kemudahan customer berbuat curang & 71 & Ragu-ragu \\
\hline 7 & Wilayah penjualan yang tak terbatas & 113 & Sangat setuju \\
\hline 8 & Mendapatkan mitra bisnis & 106 & Setuju \\
\hline 9 & $\begin{array}{l}\text { Menjaring dan mempertahankan } \\
\text { customer }\end{array}$ & 104 & Setuju \\
\hline 10 & $\begin{array}{l}\text { Memudahkan dalam mengembangkan } \\
\text { bisnis }\end{array}$ & 120 & Sangat setuju \\
\hline 11 & $\begin{array}{l}\text { Memperluas jaringan distribusi dan } \\
\text { pemasaran }\end{array}$ & 114 & Sangat setuju \\
\hline 12 & $\begin{array}{l}\text { Saling percaya antar semua bisnis } \\
\text { proses }\end{array}$ & 91 & Setuju \\
\hline 13 & Customer yang variatif & 116 & Sangat setuju \\
\hline 14 & $\begin{array}{l}\text { Susahnya untuk memeriksa kecacatan } \\
\text { barang }\end{array}$ & 110 & Sangat setuju \\
\hline 15 & Maraknya penipuan & 84 & Ragu-ragu \\
\hline 16 & Sebagai sarana promosi & 113 & Sangat setuju \\
\hline Jumlah Skor & 1780 & 111,25 & \\
\hline Rata-rata Skor & & \\
\hline
\end{tabular}

Tabel 6 di atas menunjukkan bahwa jumlah skor nilai kumulatif variabel mencapai 1780 dengan jumlah skor tertinggi $5 \times 16 \times 25=2000$, dan jumlah skor terendah $2 \times 16 \times 25=800$. Klasifikasi skor tanggapan responden dapat digambarkan dalam tahapan bobot skor dengan rentang skor 300 sebagai berikut:

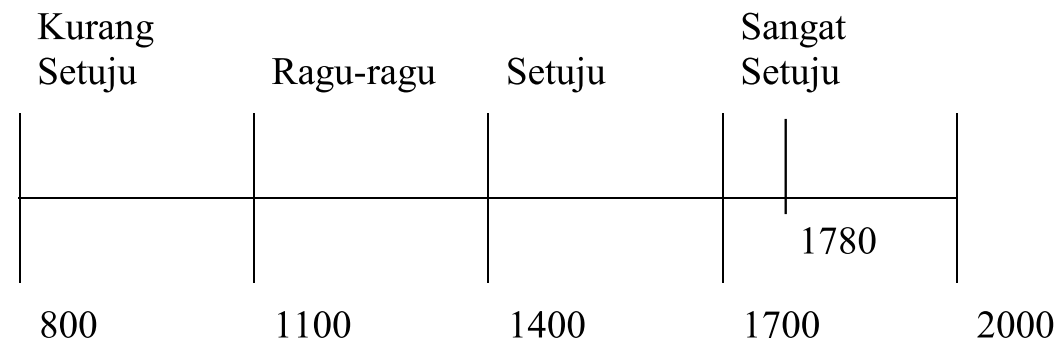

Berdasarkan tabel 6 tersebut di atas menyatakan bahwa Ibu Rumah Tangga pelaku bisnis online mengetahui dan merasakan manfaat menggunakan media e-commerce dalam bisnis yang mereka jalani, hanya saja para pelaku bisnis perlu meningkatkan kewaspadaan terhadap maraknya penipuan dan juga kemudahan customer berbuat curang, sehingga dapat mengurangi tingkat penipuan baik yang dilakukan oleh rekan bisnis ataupun customer. Begitu pula dengan kepercayaan, para pelaku bisnis harus menjaga kepercayaan yang sudah diberikan customer. 